\title{
稲沢市祖父江町旧山崎村における銀杏の配植形態と景観形成過程に関する研究
}

\section{A Study on the Planting Design of Ginkgo trees and the Process of Ginkgo trees Landscape Formation in old Yamazaki village in Inazawa, Aichi prefecture}

\author{
大橋 美紗希* 水内 佑輔** 大野 暁彦*** \\ Misaki Ohashi Yusuke Mizuuchi Akihiko Ono
}

\begin{abstract}
This study aims to clarify the feature of Ginkgo trees landscape spread all over old Yamazaki village, Inazawa city, Aichi as cultural landscape through analysis of the process of planting ginkgo trees from relationship with village structure and planting design in outside spaces. Through field surveys and mapping analysis by using aerial photographs and historical documents, the process to plant ginkgo trees can be divided to four stages as result. The places of ginkgo plantation has been shifted from surroundings of houses to the whole of the village, affected by economical reasons. Present ginkgo landscape around this area was generated from 1980's to 2000 's, when $70 \%$ of present ginkgo trees were planted, caused by a reduction in rice acreage. The aim of its plantation turned out to have changed by the time. At the beginning, there was no particular aim in planting, except symbol of premises. However, an information that ginkgo trees could be traded at high value brought about the intentional cultivation of ginkgo trees. Ginkgo plantation have come to be controlled more definitely. The control of the heights of the gingko trees can brings the characteristic landscape in Yamazaki, where people enjoy yellow leaves near tree canopies.
\end{abstract}

Keywords: Ginkgo landscape, old Yamazaki village, cultural landscape, aerial photograph キーワード：銀杏景観，旧山崎村，文化的景観，航空写真

\section{1. 背景と目的}

地域における人々の生活または生業及び当該地域の風土により 形成された景観が文化的景観と定義されるよう，人と生業との関 係で生夕出された風景への関心が高まっている。例えば, これま で多くの農地や屋敷林は文化的景観として注目されてきた。屋敷 林に関寸る研究は数多くあるが，防風・防火機能や津波の抑制効 果などに着目したものが多く, 屋敷林の変容や構成寸る空間に着 目した研究は少ない。小森ら 1) は，民家の屋敷林・外構による空 間構成と，屋敷林が維持されるか失われるかという変容との相関 性の考察をしている。石灰ら2) は砺波平野の屋敷林の分布や住民 認識を明らかにしている。

文化的景観が地域資源として観光活用される事例は数多くみら れるが3),地域の生業や暮らしとの関係で生み出された緑地が,生 活の変化により役割を失い,住民らの手によって緑地が消失し,文 化的景観の価值が損なわれる場合もある。文化的景観は地域の生 活・生業空間に価值を与えた枠組みであるが,その保全・活用策を 考えるために,その景観が地域との関わりの中でどのように形成 されたかを明らかにすることが重要であり, 造園学関連分野にお いて研究が行われてきた4)56)

愛知県稲沢市祖父江町旧山崎村 ${ }^{77}$ では，地域一帯に銀杏の景観 が広がる。従来，銀杏が形成する景観は，明治神宮外苑や御堂筋 の銀杏並木などが著名であるが，旧山崎村では地域一帯に銀杏が 広がっている。旧山崎村の銀杏は, 栽培目的で利用される一方で, 邸宅敷地内に植栽されるものもみられるため, 屋敷林及び農地と しての両側面がある。銀杏の多くは実が収穫される農作物である が, 年に 1 度行われる「祖父江銀杏黄葉祭り」では銀杏景観が観光 資源として捉えられており, 銀杏景観は地域において価值のある 景観資源としてみなされている。しかし, 研究対象地である山崎の 銀杏においても, 生活の変化により, いくつかの銀杏の切り株が見 られ, 銀杏景観が損なわれつつある。近年，山崎の銀杏が地域おこ しの資源として認識され始める中で，その価值や今後のあり方を
考えるためにも地域の生業・生活との関係をふまえて銀杏景観の 形成過程を明らかにする必要がある。

本研究の対象地を含む稲沢市は植木の産地であり, 山野8)によ って植木栽培地の地域分化とその要因を考察されている。しかし, 新興産地が形成される事例が数少ないこともあり, 農地の形成過 程に焦点が当てられた知見は限定的である。直接の先行研究とし ては, 溝口による尾張平野北西部において銀杏の分布状況, 銀杏 栽培の経営上の特色などを分析したものがある9)が,この研究は 1982 年時点のものであり, その主題はなぜこの地域で銀杏栽培が 盛んであるかの分析にあり, 銀杏が植栽される過程やそれに伴っ て形成される景観については深く分析が及んでいない。

稲沢市の公式ウェブサイトでは, 銀杏は冬季に北西の方角から 吹く伊吹おろしに対する防風林として成立したと紹介される10)が， 銀杏は落葉樹であり，この説明には疑問が残る11。

そこで，本研究では文化的景観の概念をふまえて山崎の銀杏景 観の価值について議論するため,旧山崎村に広がる銀杏景観が地 域との関わりの中でどのように形成されてきたかを明らかにする。 そのため,銀杏の配植過程とその配植形態の分析を行い, 銀杏が何 故植えられ分布が広がったか，複数スケールでの空間的な分析を 加えた再検討を行う。そのうえで山崎の銀杏景観の特性と価值に ついて考察を行う。

\section{2. 研究方法}

\section{(1) 対象地}

旧山崎村の小字である上屋敷・中屋敷は銀杏栽培発祥の地 ${ }^{12)}$ と され，旧山崎村は祖父江町の中でも最も多く銀杏がみられる地域 であり ${ }^{13)}$ ，畑地に限らず，民家の庭にも多くの銀杏が植栽されて いる。銀杏は古くから住人らに親しまれており, 銀杏栽培の経緯 に関する伝承が資料 ${ }^{14)}$ に残されている。さらに，祖父江町で最も 多く生産される銀杏の品種「久寿」の母木と言われる銀杏が「祖 父江銀杏黄葉祭り」で回遊スポットに指定されるなど，住民の間

*住友林業緑化 *東京大学大学院農学生命科学研究科附属演習林 名古屋市立大学大学院芸術工学研究科 


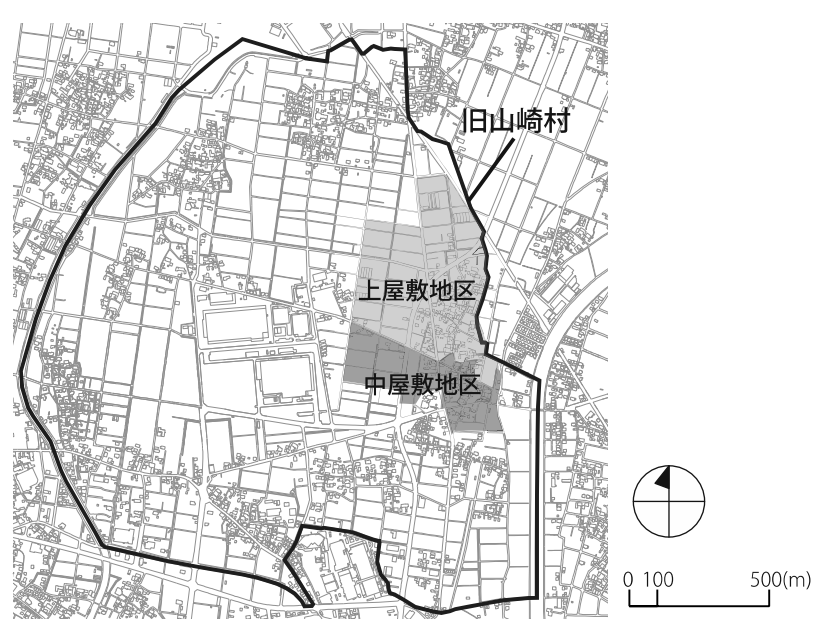

図一1 対象地 $1 / 35,000$ [国土地理院地図を元に作成］

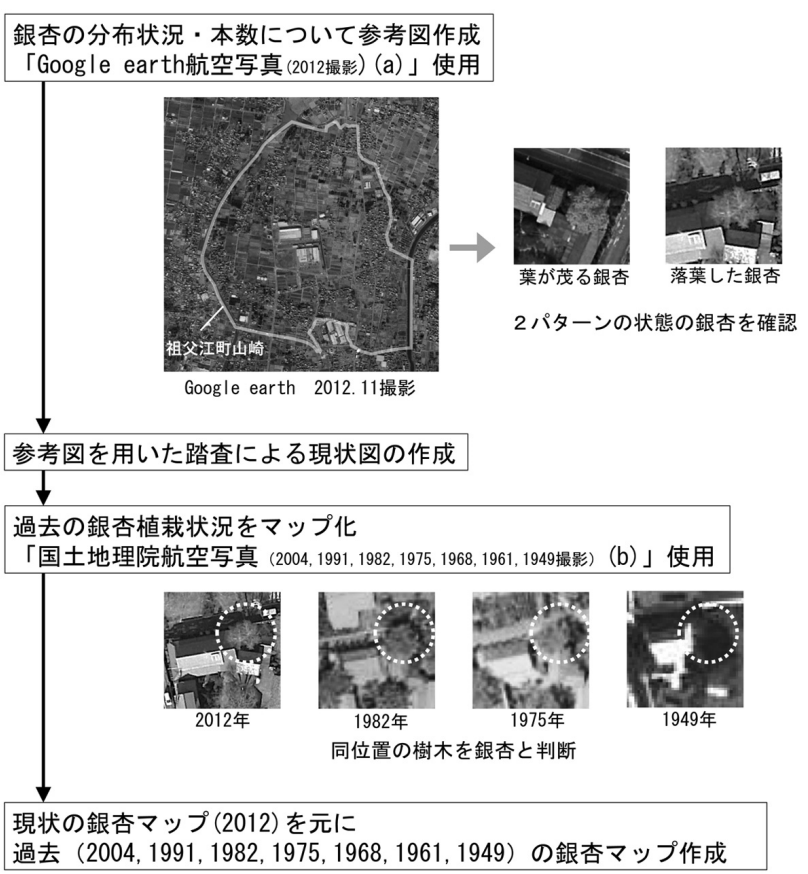

図-2 銀杏分布・本数変遷マップ化の流れ

では地域のシンボルとして認識される様子もみられる。

\section{（2）研究の流れと方法}

銀杏が地域一体に広がる過程を，航空写真と現地踏査から植栽 本数の傾向と分布の把握し，社会背景を踏まえて論証する。銀杏 栽培を中心とした農政に関する旧山崎村の社会背景については, 銀杏に関する農業記録資料, 地方史, 先行研究を資料 ${ }^{15)}$ として用 いる (3 章，4 章)。集落の邸宅の防風林を目的に植栽されたとい う言説に対し, 経時的に空間的分析を加えた再検討と, 銀杏の形態 的特徵を把握するため, 旧山崎村の上屋敷・中屋敷地区で邸宅敷 地の銀杏の配置と形態を現地調査による実測とヒアリングから明 らかにする (5 章)。これらをふまえて(1)配植場所(2)樹形(3)樹 齢(4) 本数・分布の変遷の 4 点について分析を行う。そして, 山崎 の銀杏景観の特性を考察する (6 章)。

（3）航空写真を用いた分布 · 本数の変遷分析（旧山崎村全域）

銀杏の本数・分布の変遷について, 現地踏查と航空写真の解析 により分析を行う。使用した航空写真は以下のとおりである。

Google Earth の航空写真(2012. 11 撮影) (a)

国土地理院の航空写真 (1949, 1961, 1968, 1975, 1982, 1991, 2004 撮 影) (b)
1）銀杏植栽配置の現況図作成

銀杏の分布・本数をマップ化し, 銀杏配植特性を分析するため, 現地踏査を行った。現地踏査にあたってはまず，航空写真と Google Earth のストリートビュー (2012. 3 撮影) により銀杏の分 布状況・本数について参考図を作成した。用いた航空写真(a) は 2012 年 11 月に撮影されたものであり，銀杏が黄葉した様子がみ られることから銀杏の同定が可能であったが，一部撮影時期がず れており, 葉のある銀杏と落葉した銀杏の 2 パターンの状態が見 られた。葉の茂った銀杏は円状に広がる樹冠から中心を，落葉し た銀杏は枝が広がる基となっている主幹の頂点を抽出し，その頂 部を 1 本として計数を行った。その上で現地踏査を実施した。 2017 年 9 月から 12 月にかけて筆者 1 名により計 6 日間16)行い, 2017 年 11 月 18 日に筆者ら 3 名を含む合計 5 名で踏査を行った。 2）銀杏分布・本数変遷のマップ化

銀杏の分布・本数の変遷を把握するため，(b)を用いて，1949 年〜2017 年において約 10 年ごとの銀杏本数・分布図を作成した (図一5, 図一6, 図-7)。銀杏本数・分布図を作成するにあたつ ては，(a)で銀杏がある箇所に(b)で樹木がみられた場合，その樹 木を銀杏であると判断し，(a)で作成した現況銀杏分布・本数マッ プをベースに年代ごとの銀杏の本数・分布図を作成した(図一2)。

（4）旧山崎村上屋敷 - 中屋敷地区の銀杏植栽場所の把握と実測 祖父江町旧山崎村の上屋敷・中屋敷地区(図-1)を対象として, 銀杏の樹形・樹齢の分析を行う。上屋敷・中屋敷地区には山崎に 植栽される銀杏の原木があり ${ }^{17)}$, 庭に銀杏が植栽される邸宅が他 の集落に比べて多い。庭に銀杏が植栽される邸宅, 集落内の銀杏 植栽場所 2 ヶ所, 集落外の銀杏植栽場所 1 ヶ所を対象とし, 計 43 本の銀杏で以下の 2 点について調査を行った。

i ) 銀杏の主幹切除位置, 目通り周長の実測, 配置方角

ii）邸宅の家主など, 調査地の土地の管理者へヒアリング調査 (銀 杏の樹齢，管理状況他)

2017 年 8 月から 12 月にかけて 11 日間の実測調査・ヒアリング を行った ${ }^{18)}$ 。邸宅の敷地境界については, ゼンリン住宅地図と現 地において縁石や生垣から判断した。また, 集落内, 集落外につ いては，1893 年陸地測量部発行の 2 万分 1 「稲沢」の地図に示さ れる集落範囲が全て含まれ，かつ現在において明示的な境界性を 持つ道路とした (図一-3)。

上屋敷・中屋敷地区の世帯数は 99 世帯であり邸宅数も同程度と みられる ${ }^{19)}$ 。その内 12 邸の邸宅敷地内に銀杏は植栽されており,

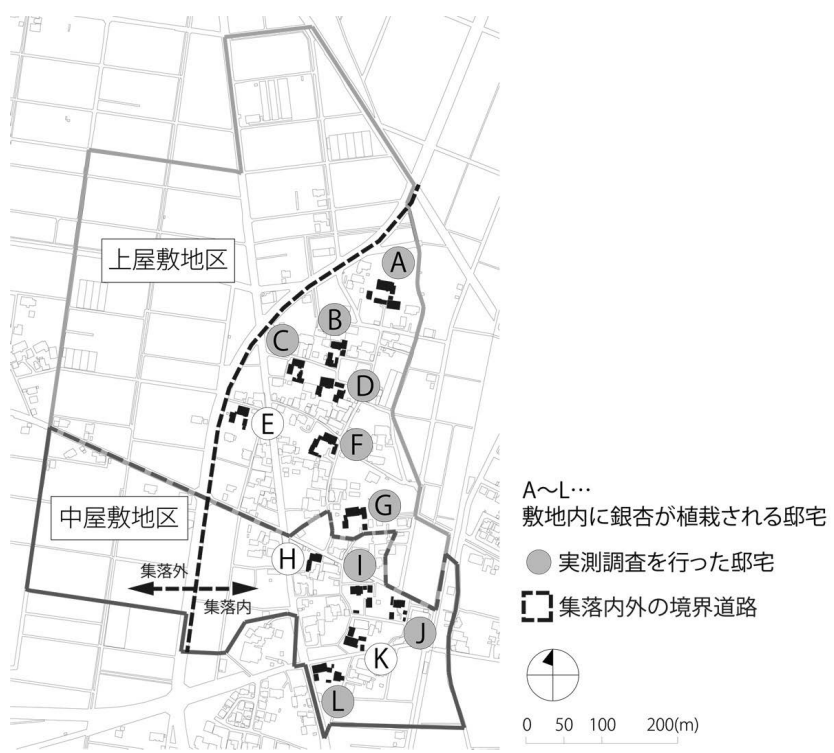

図ー3＼cjkstart調査を行った邸宅の配置図 
エリア内の北側に立地するものから順に, A 邸, B 邸, C 邸…と 寸る (図一3)。その内, 住民から調査許可が取れた 9 邸 (A, B, C, D, F, G， I，J，L 邸）で調査を行い，邸宅敷地内の銀杏は，北側 に植栽されたものから順に，(1), (2), (3)‥とする。これらをふまえ て，邸宅敷地や畑内内の銀杏本数をプロットした現況の銀杏本 数・分布図を作成した ${ }^{20)}$ (図一7)。

\section{3. 銀杏の植栽過程}

航空写真解析・踏査により得られた銀杏の本数・分布の変遷と 旧山崎村を取り巻く時代背景を図一 4 に示し, 銀杏の植栽時期を 4 期に分類した。

\section{（i ） 1920 年代以前}

銀杏が栽培・生産目的で植栽され始める以前の時代である。銀 杏の植栽理由は，非常食目的や防火目的であったという伝承が住 民の話にある。一方で，水屋の目印としてマツと共に植栽された 可能性 ${ }^{21)}$ も指摘できるが，いずれの理由も確固たる根拠はない。 銀杏が山崎で植栽され始めた時期は不明であるが，ヒアリングに よれば, 最も樹齢の長い銀杏は 400 年程度であったため (表一 1 ), 江戸時代から銀杏は植栽されていたと考えられる。

（ii） 1920 年代 1970 年代

銀杏が栽培目的として植栽され始めた時期である。旧山崎村の 銀杏から収穫される銀杏が高価格で取引されることが集落内の住 民に伝わり，多くの邸宅敷地内に銀杏は植栽され22)，山崎の銀杏 は植栽本数を伸ばした。銀杏は 1949～1961 年間におよそ 100 本, 1961 1975 年間におよそ500本の増加が航空写真による計測によ り確認され，徐々に銀杏の植栽本数が増えていたことがわかった (図一4)。

(iii) 1970 年代 2000 年代

銀杏の植栽本数が顕著に増加した時期である。銀杏の本数の分 析を行ったところ，1949〜1975 年の 25 年間に銀杏の本数は 500 本ほどの増加であったが, 1975 年から 2002 年にかけては, 10 年 ごとにおよそ 1,000 本ずつ増加している。グラフからも 1975 年か らの銀杏の増加本数は顕著に伸びていることが確認できる（図一 4)。この時期に山崎では土地区画の整理 $\left.{ }^{23}\right)$ と米の生産調整が同時 に行われたことによって，多くの田が転作のために埋め立てられ る転機となった。山崎の住民の話では，この時期景気も良く銀杏 の価格も高騰していた。山崎では，「米が不作のときはイチョウが 2 本あれば, 固定資産税を払えた」「イチョウを 1 本植えておけば 嫁支度ができた」と言われていた 立て地が銀杏畑になったと考えられる。

(iv) 2000 年代以降

銀杏の植栽本数が減少した時期である。2004 年から 2012 年に かけて銀杏の増加本数は 500 本程度であり，（iii）期と比べて植栽 本数が増えるぺースが落ちている。この要因として，転作の品目 として銀杏が着目され，他県の生産地から請われ銀杏栽培生産技 術と優良品種の苗木を全国に発信したため，銀杏栽培は全国的に 行われるようになり, 各地方で産地が形成されたことが挙げられ

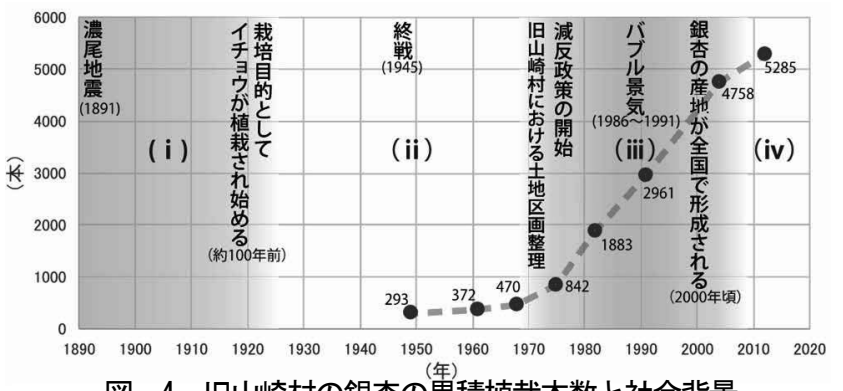

図－4 旧山崎村の銀杏の繋積植栽本数と社会背景
25)，住民らの話では銀杏の価格もそれに伴って下落したとされる。 農林水産省の調查からも 2000 年頃から特に大分県で銀杏の生産 量が増加していることがわかる ${ }^{26)}$ 。また, 山崎では生産者の高齢 化や銀杏収穫作業に伴う臭いが要因となり銀杏生産の後継者不足 が深刻化している。これらの原因で銀杏の新規植栽本数減少につ ながったとみられる。

\section{4. 植栽場所の変遷}

銀杏の本数・分布の変遷データ, 上屋敷・中屋敷地区での銀杏 の実測データの分析を行い, 植栽場所の変遷を検討した（表一 1 , 図一5, 図-6)。

銀杏の樹齢に着目した所，ヒアリングでは邸宅に植栽される銀 杏が最も古くに植栽されたものであること、その中でも邸宅敷地 内の中心付近と端に植栽されたもので植栽時期が分かれることが わかった。そこで, 2 種類の分類を行った。

( I ) 中心配植タイプ

母屋と付属屋に挟まれた，邸宅敷地の中心付近の空間に植栽さ れる銀杏の配植タイプである。

表-1 上屋敷・中屋敷地区における銀杏実測結果

\begin{tabular}{|c|c|c|c|c|c|c|c|c|c|}
\hline & No. & \begin{tabular}{|l} 
配置 \\
タイプ \\
\end{tabular} & \begin{tabular}{|l|} 
配置 \\
方位 \\
\end{tabular} & $\begin{array}{l}\text { 主幹 } \\
\text { 本数 }\end{array}$ & \begin{tabular}{|l|} 
主幹 \\
切除痕
\end{tabular} & \begin{tabular}{|l|}
$\begin{array}{l}\text { 主幹切除痕 } \\
\text { 位置 }(\mathrm{m})\end{array}$ \\
\end{tabular} & $\begin{array}{l}\text { タイ } \\
7\end{array}$ & 樹齢 & \begin{tabular}{|l} 
幹周り \\
(cm)
\end{tabular} \\
\hline$A$ 邸 & (1) & 境界 & 北西 & 1 & あり & 140 & d) & 70 & 160 \\
\hline \multirow[t]{2}{*}{ B邸 } & (2) & 中心配置 & - & 1 & あり & 205 & c) & 120 & 205 \\
\hline & (3) & 中心配置 & - & 1 & あり & 215 & c) & 100 & 245 \\
\hline C邸 & (4) & 境界 & 南 & 1 & あり & 235 & c) & 90 & 255 \\
\hline \multirow[t]{2}{*}{ D邸 } & (5) & 境界 & 北東 & 1 & あり & 130 & d) & 70 & 347 \\
\hline & (6) & 中心配置 & - & 1 & なし & - & a) & 400 & 390 \\
\hline \multirow[t]{4}{*}{ F邸 } & (7) & 境界 & 北西 & 1 & あり & 117 & d) & 60 & 290 \\
\hline & (8) & 境界 & 北西 & 2 & $*$ & 100 & e) & 60 & 360 \\
\hline & (9) & 境界 & 北西 & 1 & あり & 133 & d) & 60 & 170 \\
\hline & (10) & 中心配置 & - & 4 & $*$ & - & e) & 90 & 360 \\
\hline \multirow[t]{3}{*}{ G邸 } & (11) & 境界 & 北 & 1 & なし & - & a) & 100 & 230 \\
\hline & (12) & 中心配置 & - & 2 & なし & - & b) & 180 & 369 \\
\hline & (13) & 境界 & 西 & 1 & あり & 130 & d) & 70 & 220 \\
\hline \multirow[t]{4}{*}{ I邸 } & (14) & 境界 & 北西 & 1 & あり & 115 & d) & 50 年以前 & 140 \\
\hline & (15) & 境界 & 北西 & 1 & あり & 120 & d) & 50年以前 & 220 \\
\hline & (16) & 境界 & 南東 & 1 & あり & 230 & c) & 50年以前 & 210 \\
\hline & (17) & 境界 & 南東 & 1 & あり & 240 & c) & 50年以前 & 200 \\
\hline J邸 & (18) & 中心配置 & - & 1 & なし & - & a) & 150 & 287 \\
\hline \multirow[t]{2}{*}{ L邸 } & (19) & 境界 & 東 & 1 & あり & 205 & c) & 80 & 218 \\
\hline & (20) & 中心配置 & - & 1 & あり & 220 & c) & 100 & 210 \\
\hline \multirow{5}{*}{$\begin{array}{l}\text { 集落内 } \\
\text { 未利用地 } \\
A \\
A\end{array}$} & (21) & & & 2 & なし & - & b) & 80 & 不明 \\
\hline & (22) & & & 1 & あり & 125 & d) & 60 & 155 \\
\hline & (23) & & & 1 & あり & 90 & d) & 60 & 100 \\
\hline & (24) & & & 2 & なし & - & b) & 60 & 不明 \\
\hline & (25) & & & 1 & あり & 80 & d) & 60 & 160 \\
\hline \multirow{6}{*}{$\begin{array}{l}\text { 集落内 } \\
\text { 未利用地 } \\
\text { B }\end{array}$} & (26) & & & 1 & あり & 220 & c) & 50 & 180 \\
\hline & (27) & & & 1 & あり & 80 & d) & 50 & 200 \\
\hline & (28) & & & 1 & あり & 135 & d) & 50 & 170 \\
\hline & (29) & & & 1 & なし & - & a) & 50 & 228 \\
\hline & (30) & & & 1 & あり & 80 & d) & 50 & 206 \\
\hline & (31) & & & 1 & あり & 115 & d) & 50 & 197 \\
\hline \multirow{12}{*}{ 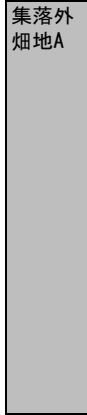 } & (32) & & & 1 & あり & 164 & d) & 50 & 160 \\
\hline & (33) & & & 1 & あり & 166 & d) & 50 & 150 \\
\hline & (34) & & & 1 & あり & 170 & d) & 50 & 105 \\
\hline & (35) & & & 1 & あり & 140 & d) & 50 & 143 \\
\hline & (36) & & & 1 & あり & 130 & d) & 50 & 143 \\
\hline & (37) & & & 1 & あり & 130 & d) & 50 & 95 \\
\hline & (38) & & & 1 & あり & 140 & d) & 50 & 88 \\
\hline & \begin{tabular}{|l|}
399 \\
\end{tabular} & & & 1 & あり & 126 & d) & 50 & 66 \\
\hline & (40) & & & 1 & あり & 130 & d) & 50 & 86 \\
\hline & (41) & & & 1 & あり & 110 & d) & 50 & 74 \\
\hline & (42) & & & 1 & あり & 150 & d) & 50 & 150 \\
\hline & (43) & & & 1 & あり & 135 & d) & 50 & 238 \\
\hline
\end{tabular}




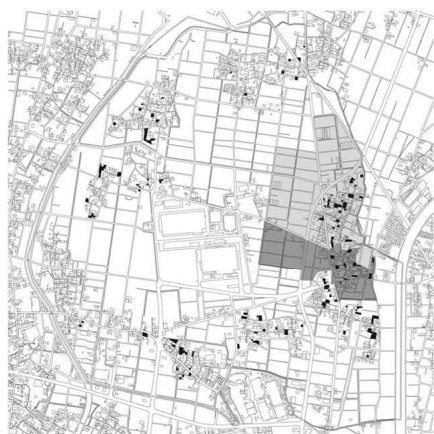

1949年

…上屋敷地区

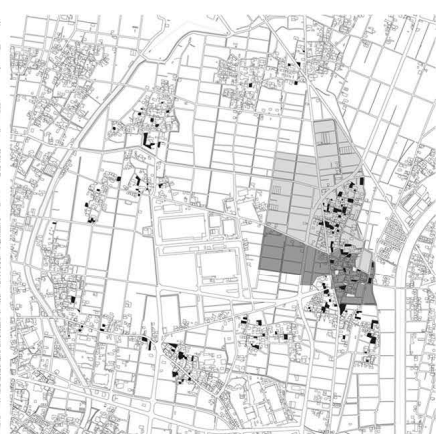

1961年

図－5＼cjkstart旧山崎村銀杏分布変遷マップ $(1949,1961,1975,1982)$

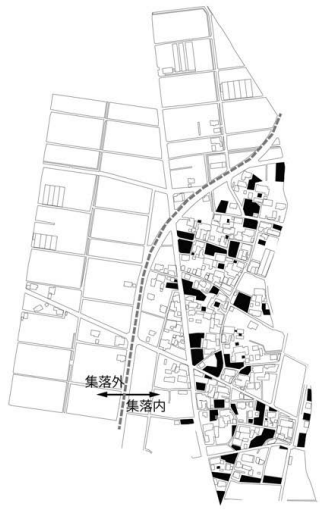

1975年

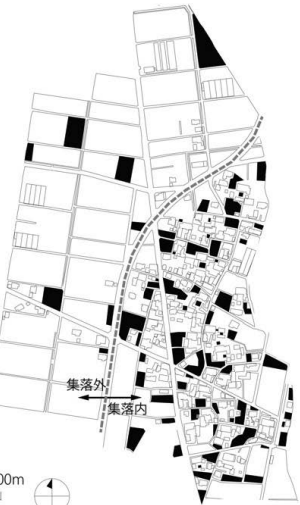

1982年

*図の大きさを考慮し、銀杏が植载される邸宅敷地や畑の地割を黒塗 図一6 上屋敷 - 中屋敷地区銀杏分布変遷マップ $(1975,1982)$

\section{(II) 境界配植タイプ27)}

邸宅敷地の端や邸宅の裏などに単体，あるいは複数まとめて植 栽された銀杏の配植タイプである。

銀杏は邸宅敷地内外周に植えられ始めたという伝承が資料に残 されるが28)，その中でも「中心配植タイプ」は約 100 年前に植栽 された。境界配植タイプ」はそれ以降に植栽されており (表一1), 当初は邸宅敷地の中心付近で植栽されていたものが，邸宅敷地の 中心付近から端や董側など敷地境界付近一植栽されるようになっ たことが明らかとなった。

集落内未利用地に銀杏が植栽され始めた時期の明確な特定は困 難であったが，樹齢を比較すると，邸宅内の銀杏より後に植栽さ れていることがわかる。航空写真解析からは 1949 年時点で集落内 の耕地に存在した様子が確認されたため，栽培目的で本格的に植 栽され始めた 1920 年代〜1940 年代（ii期初頭）に，銀杏の植栽 場所が邸宅敷地内から集落内未利用地一広がり始めたことが推察 される。

集落外畑地への広がりについては，図一6 から(iii)期初頭に 当たる 1970 年代頃に銀杏が植栽され始めた時期に, 顕著に銀杏の 植栽範囲が集落内から集落外一広がることが確垫された。

この点は，時代背景を元に 3 章で指摘した，（iii）期の米から銀杏 への転作という事情からも裏付けられる。

\section{5. 配植形態と樹形からみる植栽意図の変遷}

上屋敷・中屋敷地区での銀杏の実測データを元に，銀杏の配植 形態・樹形について分析し，植栽場所ごとの植栽用途の際を検討 した。

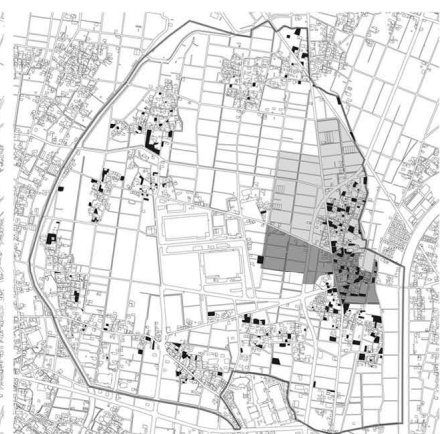

1975年

1982年

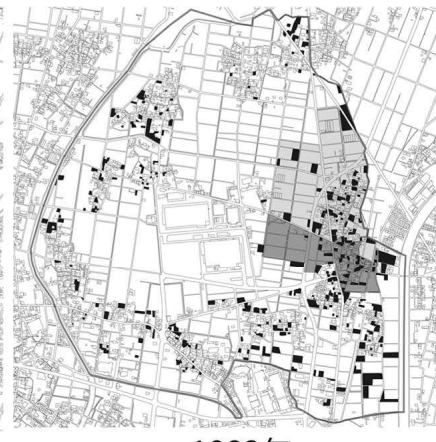

*図の大きさを考慮し、銀杏が植栽される邸宅敷地や畑の地割を黒塗り $0200(\mathrm{~m})$

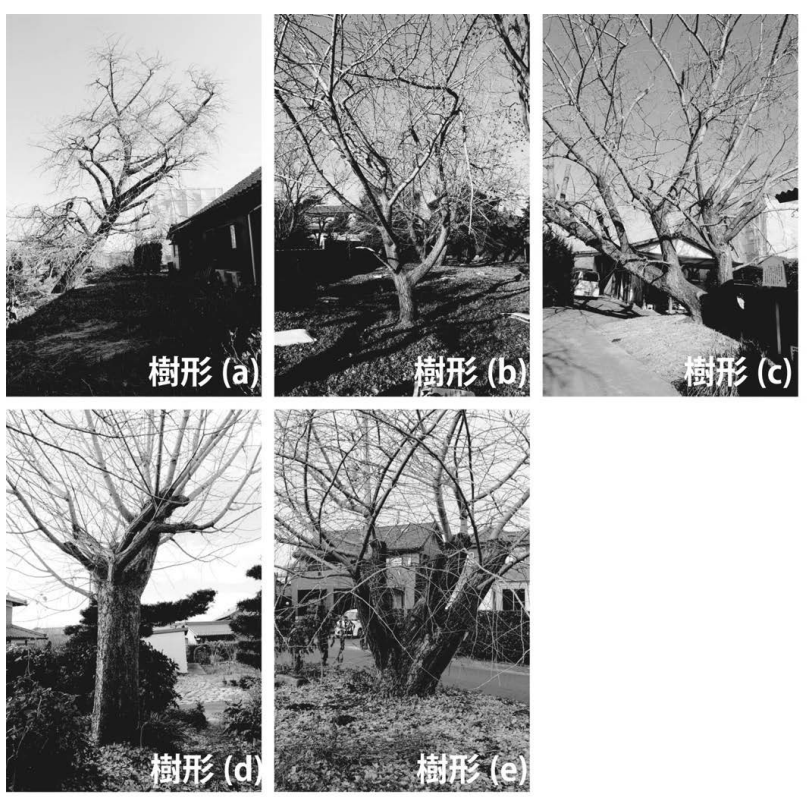

写真-1＼cjkstart樹形タイプ別の銀杏

銀杏の樹形は, 人為的に操作されたものとそれ以外に分かれた。 本研究では人為的に操作された痕跡の判断基準として, 主幹の切 除痕の有無, 主幹の本数とし，5つに分類した（写真一 1 )。 樹形 a) 切除痕なし一単幹型 (4 本)

主幹が切除されていないため，切除されたものに比べると樹高 が高い。意図的に樹形を操作されていないとみなした。 樹形b) 切除痕なし一分岐型 (3 本)

主幹が切除されていないため，切除されたものに比べると樹高 が高い。主幹が複数本存在する，株立ちの樹形。意図的に樹形を 操作されていないとみなした。

樹形 c) 切除痕あり一単幹型 (主幹切除位置 $2 \mathrm{~m}$ 以上) (8 本)

主幹が人の身長より高い位置で切除される。樹形を小さくまと める意図を持って樹形を操作したものとみなした。

樹形 $\mathrm{d}$ ) 切除痕あり一単幹型 (主幹切除位置 $2 \mathrm{~m}$ 以下) (26 本)

主幹が人の身長より高い位置で切除されたもの。銀杏の収穫を 容易にする目的（果樹栽培でよく用いられる手法）で樹形を操作 されたものとした。

樹形e) 切除痕あり一分岐型 (2 本)

調査を行った 43 本の中で 2 本みられたが, 幹の分岐が人為的な 切除によるものか, 自然発生したものかを目視での判断が困難で あったため，本研究では例外とした。 


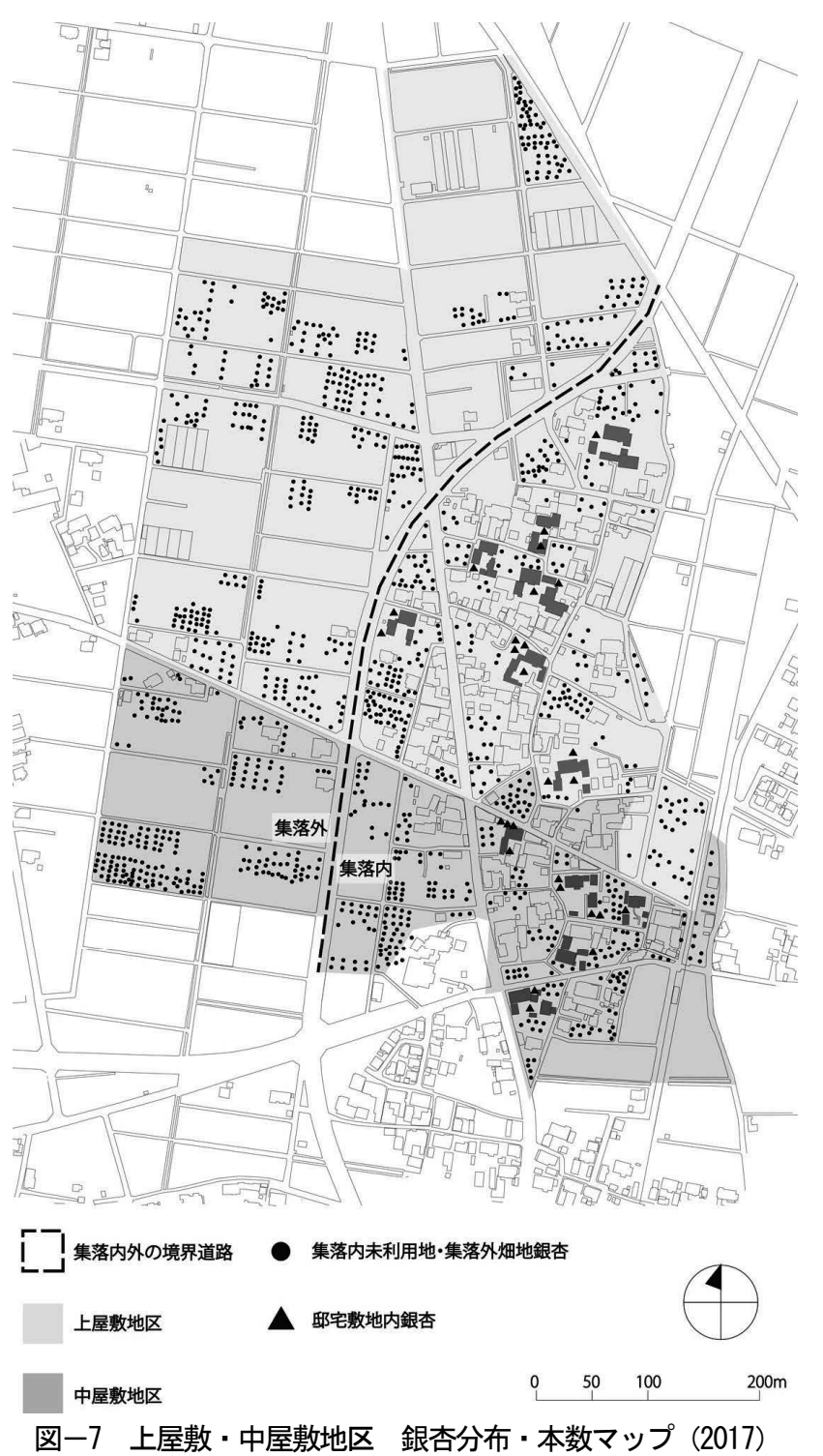

\section{（1）邸宅敷地とその外周の銀杏}

調査を行った 9 邸の邸宅敷地内には, 計 20 本の銀杏が植栽され ていた。邸宅敷地内に植栽される銀杏は 1 邸あたり 1 4 本で, 密 植されたものは最大で 3 本であった。このことから畑地のような 本格的な栽培・生産を目的とした植栽意図は無かったことが推察 される。

調査を行った 20 本のうち 8 本で主幹が胸高程度の切除痕が見ら れた。邸宅敷地内に植栽された銀杏のうち半分ほどは栽培上の目 的で樹形を管理されたものであったと考えられる（表一1）。

邸宅敷地内の銀杏「中心配植タイプ」，「境界配植タイプ」の樹 形・配植形態を分析するとそれぞれに特徵が現れたため，異なる 意図を持って植栽されたことがわかった。

\section{1) 中心配植タイプ}

9 邸の邸宅のうち 6 邸(計 7 本) で中心配植タイプがみられた(表 $-1)$ ここのうち 5 邸では 1 邸につき 1 本，B 邸でのみ 2 本植栽さ れていることから，1 邸あたりの植栽本数は少ない。また，邸宅 の母屋玄関や戸口など住民が頻繁に使う空間から視認できる位置 か, あるいは戸口から母屋へのアプローチ沿いに植栽されており, 邸宅のシンボルとして植栽されたと推察できる。

さらに樹形に着目寸ると, 樹形c)の樹形が 3 本, 樹形a)の樹形 が 2 本, 樹形e)・樹形b) がそれぞれ 1 本ずつと統一性が無く, 何 らかの強い利用意図を持って植栽・管理されたわけではないこと
がわかった。また，樹形 d) は確認されず，「中心配植タイプ」は 植栽された当初, 栽培を容易にするための樹形管理がされていな いことがわかった。

\section{2）境界配植タイプ}

境界に配植されるものには，9 邸の邸宅の内 8 邸の邸宅（計 13 本）にみられ，植栽場所と植え方から 3 種類の配植パターンがみ られる (表一 1 )。単木で邸宅の裏に植栽される場合, 敷地の複数 箇所に点在する場合，あるいは一箇所につき複数本まとめて植栽 される場合がある。邸宅の母屋玄関や戸口など住民が頻繁に使う 空間から視認できないなど居住空間から離れた場所に植栽された ものが 13 本中 12 本と, 多くを占めたことから, 鑑賞などの植栽 意図は無く，実用目的で植栽されたことが推察できる。

銀杏配植位置の邸宅内における方位に着目した所, 八方位区分 でタれば北西の方位に植栽される銀杏が 13 本中 5 本と最も多くを 占めた（表一1）。しかし，「境界配植タイプ」が複数本配植される 邸宅 3 つの邸宅の内 $\mathrm{G}$ 邸, I 邸に着目寸ると, 北西にだけ植栽され るのではなく邸宅敷地内の複数箇所に植栽されている様子がみら れた（図一7）ことや,他の「境界配植タイプ」8 本の配置方位を みると東, 西, 南, 北側の方位でそれぞれ銀杏がみられたことから, 銀杏配植位置の方位については統一的な傾向を見出寸ことは困難 である。最も樹齢が高いとされる銀杏が「中心配植タイプ」であ ることも考慮すれば、伊吹おろしに対する防風機能を期待して銀 杏が植栽されたとは考えにくい。

\section{（2）集落内未利用地の銀杏}

銀杏は単木で植栽されることは少なく, ほとんどが数本〜数 10 本程度でまとまって植栽される。また，方角に偏らず植栽されて おり，集落内の未利用地が銀杏栽培のための場所として扱われて いるものとみられる。

樹形に着目したところ, 調査を行った銀杏 11 本中 7 本と半数程 度が樹形 d) タイプで,「境界配植タイプ」と同様に, 栽培を意図 して植栽管理された傾向がみられる（表-1）。一方で, 例外が半 数みられたため, 銀杏栽培の手法が確立していなかったか, ある いは本格的な栽培を意図していなかったものと推察できる。

\section{（3）集落外畑地の銀杏}

集落外畑地に植栽される銀杏は単木で植栽されることは少なく, 数本一数 10 本，多い畑では 100 本程度がまとまって植栽される。 また，「集落内銀杏」と同様に方角に偏らず植栽されており, 集落 外畑が銀杏栽培のための園地として扱われているものとみられる。

樹形に着目したところ, 調査を行った銀杏 12 本が樹形 d) タイ プであり，樹形の統一性から栽培を強く意図して植栽・管理され た傾向を読夕取れる（表一 1 )。これより, 共通の銀杏栽培の手法 が確立され, 本格的な栽培を意図して銀杏は植栽されたものと推 察できる。

\section{6. おわりに}

稲沢市祖父江町山崎において, 邸宅内, 集落内, 集落外, 3 つ のスケールで銀杏の分布・本数変遷及ひ配植形態・樹形・樹齢に ついて分析を行ったところ，以下の 3 点が明らかとなった。

\section{(1) 銀杏の植栽過程}

銀杏の植栽の分布過程は 4 期に分けられた。植栽場所は, 銀杏 栽培の発見や，価格の上昇，生産調整などの社会的背景に影響を 受けながら, 集落の邸宅敷地内, 集落内未利用地, 集落外畑地一 と次第に集落外一向かって銀杏の植栽範囲が広がったことが航空 写真を用いた分析からわかった。現在の地域一体に広がる銀杏畑 風景の形成は比較的新しく, 1980 年代〜2000 年代にかけて形成さ れた。現在みられる銀杏の約 $70 \%$ このの時期に植栽されたが，こ れは土地区画整理と減反政策によって, 多くの集落外の田畑が銀 杏栽培に転作した影響によると考えられる。 


\section{（2）植栽意図の違いによる配植場所と樹形}

時代により植栽目的に違いがあることがわかった。銀杏は当初, 栽培や防風など特定の利用目的を持たずに植栽され始め，邸宅敷 地の中心付近に植栽され，シンボルのように扱われていた。銀杏 が高価格で取引される情報が集落内に広まったことをきっかけと し, 銀杏栽培を意図して邸宅内の各所に植栽されるようになった。 このように, 経時的かつ, 邸宅スケールまで空間的に再検討した結 果，伊吹おろしに対寸る防風林としてイチョウが植栽されたので はないことがわかった。また, 銀杏の植栽意図や場所が変遷するに 伴い，樹形が統一して管理されるなど，より明確な栽培意図を持 つて植栽管理されるようになった。

\section{（3）山崎の銀杏の景観特性と今後の展望}

栽培意図を持って植栽された銀杏は，人の胸高程度で主幹切除 痕がみられるなど，樹形に特性が表れている。銀杏は並木など, 風高木のものが著名であるが，銀杏栽培のため植えられた山崎の 銀杏は樹高が抑制され，アイレベルでも黄葉を見られることが， 旧山崎村の銀杏景観の特性である。

一方で，高齢化などにより，銀杏収穫を止めた場合には，樹高 の抑制も止められる。このため当該の銀杏だけでなく，その周囲 の銀杏の樹高も高くなっていく。ヒアリングからもこの傾向はす でに表れていることが確認されており，山崎の銀杏景観の形態的 特性が失われる危険性もある。

本研究では, 山崎の銀杏景観が人と生業の関係から生み出され, 生活の変化に伴、経時的に景観形成のされ方を変遷させながら現 在に至るまでの過程と, 形成された銀杏景観の特性を明らかにし た。この山崎の銀杏景観は，まさに地域における人々の生活また は生業及び当該地域の風土により形成された文化的景観である。 その文化的価值や地域資源としての有用性から保全・活用される べきであるが, 住民らからは, 山崎から植栽されていた邸宅内の銀 杏が，倒木の危険や葉の処理に困った住民らによって伐採されつ つあるという話が聞かれ, 生業との密接な関係を持ついくつかの 文化的景観と同じく人々の生活の変化により景観が失われつつあ る傾向がみられるのが現状である。

山崎では, 近年, 銀杏景観に地域資源としての価值を見出し観光 利用する動きがあるが29), どのような銀杏景観を形成していくか が問われる局面となる。本研究では，山崎の銀杏景観の形態的特 性を明らかにしたが，アイレベルでも黄葉を見られる銀杏をいか に保全していくかが一つの課題となる。また，文化的景観を生か した観光といった側面では、その景観が形成された背景も重要視 されつつあるが30、配植場所や樹形の違いはそれぞれの時代の背 景によって生多出されたものである。地域一帯に広がる眼前の銀 杏景観がいかに形成されていったかを可視化する試みも必要とな る。山崎の銀杏文化を保存し後世に遺すためにも, これまで地域と の関わりの中でどのように銀杏景観が形成・保全されてきたかを 踏まえ, 今後の銀杏と共存できる銀杏景観と地域の関係の在り方 を模索していく必要がある。

謝辞：本論文執筆にあたり,祖父江町商工会, JA 愛知西の皆様に は資料の提供など多大なる御支援を頂いた。また, 祖父江町山崎の 皆様には調査や資料の提供などで, 多大なる御協力・御支援を頂い た。本研究は公益財団法人日比科学技術振興財団の研究開発助成 を受けたものである。ここに記して厚く謝意を表する。

\section{補注及び引用文献}

1）小森美咲・村上暁信(2013）: 屋敷林の変遷と民家の空間構成に関する研究 : つくば 市洞下集落を事例に : 都市計画論文集 48(3), 363-368

2) 石灰希・深町加津枝・奥敬一・柴田昌三 (2018) : 砺波平野の屋敷林に対寸る住民の
認識と保全のための対応策 : ランドスケープ研究 81 (5), 549-552

3）小林駿司・宮脇勝 (2014) : 鴨川市大山千枚田の風景保全のための意識と課題に関す 万研究: 大山千枚田保存会, 農業従事者, 行政の風景資源価值と資金に関寸る意識 調查 : 都市計画論文集 49(1), 77-82

4）南里美緒・横張真・落合基継（2009）: 近江八幡の水郷景観におけるヨシ原の変遷と その文化的景観としての保全策 : ランドスケープ研究 72(5), 731-734

5）七海絵里香・石井佑也・大澤啓志 (2016) : 那坷川における箈景観の今日的意義と存 続要因:ランドスケープ研究 79(5), 559-564

6）木村真也・村上修 (2011)：中山間地域における茶園景観に関する研究：滋賀県 東近江市奥永源寺地域について : 都市計画論文集 46(3)，151-156

7）明治行政村の1つで，1906 年に旧祖父江町に合併された。

8）山野明男(1981）: 愛知県稲沢市を中心とする植木栽培の立地配置 : 人文地理 $33(5), 444-457$

9）溝口晃之(1982) : 尾張平野北西部の銀杏栽培の地理学的研究 : 地理学報告 55, 15-22

10）稲沢市: 祖父江のぎんなん

〈http://www. city. inazawa. aichi. jp/ka_annai/noumu/ginnan/top. html〉2018. 1 .30 参照

11）溝口も, 伊吹おろしが吹く北西方向以外にも銀杏が植栽されていることからこの説 明には疑義を示している。

12）日本果樹種苗協会編(1991）: 特産のくだもの一ぎんなん：日本果樹種苗協会, 9-10

13）溝口晃之(1982): 尾張平野北西部の銀杏栽培の地理学的研究: 地理学報告 55, 15-22

14）日本果樹種苗協会編(1991）: 特産のくだもの一ぎんなん：日本果樹種苗協会, 31 戸田七郎: 祖父江町地域農家のギンナン栽培(発行年不詳) : 愛知県稲沢市農業改良 普及所, $1-2$

15）祖父江町史編さん委員会(1979）：祖父江町史, 1297pp 祖父江町教育会 (1932) : 祖父江町誌 : 祖父江町教育会, 701pp 戸田七郎(発行年不詳) : 祖父江町地域農家のギンナン栽培 : 愛知県稲沢市農業改 良普及所, $16 p p$

日本果樹種苗協会編(1991）: 特産のくだもの-ぎんなん：日本果樹種苗協会, 89pp ふるさと今昔写真集編さん委員会(1985)：ふるさと今昔写真集 祖父江町:祖父 江町役場, 132pp

16) $2017.9 .3, \quad 2017.9 .10, \quad 2017.10 .5, \quad 2017.10 .20, \quad 2017.11 .22, \quad 2017.12 .26$

17）日本果樹種苗協会編(1991）: 特産のくだもの一ぎんなん：日本果樹種苗協会, 25

18）ヒアリング・実測調査日 (2017.8.8 2017.8.27 2017.9.10 2017.9.16 2017.9.26 2017.10.4 2017.10.5 2017.10.20 2017.11. 18 2017. 12.20 2017. 12.26)

19）稲沢市: 人口・世帯数 : 最新行政区別人口調査表 〈http://www. city. inazawa. aichi. jp〉2017. 12. 01 参照

20）作成した図には敷地ごとに本数がプロットしてあるが, レイアウトの都合上記入し ていない。

21）毎日新聞(1985.7.2) 尾張平野で形成される輪中集落内に建築 される水屋の目 印として，マツと共にイチョウが植栽される習慣があったとされる。祖父汀町史， ヒアリング調査によれば祖父江町では松の植栽が支配的であったとされる。

22) 戸田七郎(発行年不詳) : 祖父江町地域農家のギンナン栽培:愛知県稲沢市農業改良 普及所, $1-2$

日本果樹種苗協会編(1991) : 特産のくだもの-ぎんなん: 日本果樹種苗協会, 41-42

23）愛知県営ほ場整備事業祖父江地区

24）日本果樹種苗協会編(1991）: 特産のくだもの一ぎんなん：日本果樹種苗協会, 41-42 ヒアリング調査でも，住民から同様の話があった。

25）日本果樹種苗協会編(1991）：特産のくだものーぎんなん：日本果樹種苗協会, 41-42

26) 農林水産省 : 特定果樹生産動態調査 〈http://www. maff. go. jp〉2018. 1.30参照

27）航空写真が 1949 年以前のものを入手できなかったことから、特にそれ以前の場合 には「中心配植タイプ」であったものが分筆の際後付け的に「境界配植タイプ」に なった可能性は限定的ではあるが存在する。

28）日本果樹種苗協会編(1991）: 特産のくだもの一ぎんなん：日本果樹種苗協会, p41 ヒ アリング調査でも，住民から同様の話があった。

29）「稻沢市観光まちづくりビジョン キックオフシンポジウム」2018, 3,10

30）下村彰男 (2016) : 風景計画を俯瞰する : 風景計画研究 1, 4-5 